\title{
Posterior Capsule Opacification and Nd-YAG rates evaluation in a large series of pseudophakic cases
}

\author{
Iliescu Ioana Madalina, Constantin Maria Alexandra, Cozma Cristina, \\ Moraru Ozana Manuela, Moraru Cristian Mircea \\ Oculus Eye Clinic, Bucharest, Romania \\ Correspondence to: Ioana Madalina Iliescu, MD, \\ Oculus Eye Clinic, 91-111 Calea Floreasca, District 1, Bucharest, Romania, \\ Mobile phone: +40721 340 480, Fax: +4021 31780 73, E-mail: madailiescu@yahoo.com
}

Accepted: December 18th, 2017

\begin{abstract}
Purpose: To evaluate the influence of Intraocular Lens (IOL) material and design on Posterior Capsule Opacification (PCO) and Neodymium-YAG (Nd-YAG) rates in eyes implanted with different Posterior Chamber Intraocular Lenses (PC IOLs) designs at the end of uncomplicated cataract surgeries.

Setting: Oculus Eye Clinic, Bucharest, Romania.

Design: Retrospective, observational study.

Methods: This study comprised 4805 eyes operated for cataract in 2012 and 2013 with a post-operative average follow up of $40 \pm 6,15$ months (27-54 months). The PCO and Nd-YAG rates were recorded and compared among different IOL materials and designs and among different pathology groups.

Results: From 4805 IOLs implanted, 2560 (53,27\%) were hydrophilic and 2245 (45,73\%) hydrophobic, 2937 (61\%) were aspherical and 1868 (39\%) spherical. We found statistical significant differences in the PCO and Nd-YAG rates between hydrophilic $(18 \%$ and $14 \%$ respectively) and hydrophobic lenses $(4 \%$ and $2 \%$ respectively) $(p<0.0001)$. There were also statistically significant differences in the sub-group of hydrophilic aspheric IOLs, finding lower PCO and Nd:YAG rates with the C-loop haptics configuration $(12,6 \%$ and $3,3 \%$ respectively) compared with the broad optic/ haptic junction $(29,75 \%$ and $24,73 \%$ respectively) $(\mathrm{p}<0.001)$. No statistically significant differences on PCO and Nd:YAG rates were found for the different associated pathologies ( $\mathrm{p}>0.05)$.

Conclusions: Hydrophilic lenses showed statistically higher PCO and Nd:YAG rates than hydrophobic lenses. In contrast, the optic asphericity and the associated pathologies had no influence on the PCO and Nd:YAG rates. IOL design and material seem to be the main characteristics influencing PCO and Nd-YAG rates.
\end{abstract}

Keywords: IOL design, IOL material, Nd-Yag rates, posterior capsule opacification

Abbreviations: LECs $=$ lens epithelial cells

\section{Introduction}

Cataract is a common and significant cause of visual impairment [1]. During surgery, it is impossible to mechanically remove all lens epithelial cells (LECs) from the capsular bag. The remaining equatorial LECs will migrate, undergo metaplasia, and form posterior capsule opacification (PCO).

PCO causes light scatter within the visual axis and produce visual disability [2]. PCO is 
considered the most common reason for reduced visual acuity after cataract surgery in otherwise healthy eyes [3]. PCO also degrades various aspects of visual function, including contrast sensitivity [4-6], glare disability [7-9], color vision and stereoscopic vision [10]. The treatment for PCO is Neodymium:YAG (Nd:YAG) laser capsulotomy which, although considered safe, may lead to some complications, including intraocular lens (IOL) damage, intraocular pressure (IOP) elevation, cystoid macular edema or retinal detachment [11].

Studies have shown a correlation between PCO rates and IOL characteristics, such as edge design [12] and optic material [13,14]. Also, creating a conti bnuous, centered and perfect sized anterior capsulorhexis can influence PCO occurrence [15].

In our study, we objectively quantified and compared PCO and Nd-YAG rates for all Posterior Chamber (PC) IOLs implanted in eyes operated for cataract in 2012 and 2013 in Oculus Eye Clinic, Bucharest. We recorded the PCO and Nd:YAG rates for hydrophilic/ hydrophobic and spherical/ aspherical IOL groups and evaluated the influence of IOLs characteristics on PCO and $\mathrm{Nd}$ :YAG rates. We also evaluated all the ocular and nonocular concurent pathology and their influence on PCO rates.

\section{Methods}

Patients with uneventful cataract surgeries and no postoperative complications who were operated in 2012 and 2013 at the Oculus Eye Clinic, Bucharest, Romania, were included in this retrospective observational clinical trial. The study was approved by the Ethics Committee, Oculus Eye Clinic, Bucharest (02/ 2016) and registered with the Romanian National Agency of Drugs and Medical Devices. Our study is in agreement with "human and animal rights" and respects the Helsinki Declaration of 1975 revised in 2000 and 2008.

Patients' charts were included in the study after examining all surgeries reports and postoperative information stored in the 20122013 Oculus Registry and only the charts that complied with the inclusion/ exclusion criteria were selected.

The inclusion criterion was all uncomplicated eyes operated for cataract from
January 2012 to December 2013. Exclusion criteria were eyes with ocular preoperative associated inflammatory pathology (uveitis) or trauma, complicated intraoperative cases with posterior capsular rupture, complicated postoperative cases: endophthalmitis, inflammation of different etiology of anterior or posterior pole or those with no follow-up visits.

All surgeries were performed under topical anesthesia by five surgeons using ultrasound technology (INFINITI $®$ Vision System, Stellaris PC or CENTURION® Vision System) followed by the polishing of the posterior capsule and the implantation of it in the bag PC IOL (of in the bag- without it). A small percentage $(1.19 \%)$ of eyes had a capsular tension ring implanted addressing the zonular laxity. Few surgeries (1\%) were followed by same session intravitreal injection of either Bevacizumab or Triamcinolone Acetonide for Diabetic Macular Edema (DME) or wet Age Related Macular Degeneration (AMD). Some surgeries $(3,5 \%)$ were performed by using the femtolaser technology (LenSx® Laser System). Each patient received a PC IOL spherical or aspheric, hydrophilic or hydrophobic.

All the patients received the same postoperative treatment: antibiotic and steroid fixed combination five times a day for two weeks, followed by steroid drops three times a day for another two weeks.

The follow-up examinations were at first day, first month, and 3 months to one year postoperative, depending on ocular status. Further examinations (at every 3, 6 or 12 months) up to over 4 years (max 54 months) of follow-up were scheduled dictated by ocular features, referring the doctors' requests or the patients' visual complaints/ demands.

The best distance and near corrected visual acuity (VA), anterior and posterior segment dilated slip lamp examination and tonometry were evaluated at each follow-up visit. The PCO was evaluated subjectively with the retro illumination of the slit lamp. PCO was considered when Elschnig' Pearls or fibrosis could be noticed on the posterior capsule correspondent to the capsulorhexis opening.

Nd:YAG laser treatment was performed when BDCVA decreased at least $20 \%$ due to PCO occurrence. 
PCO and Nd:YAG rates were evaluated for the different IOL material and design groups included in the present study.

Additionally, cases were assigned into different pathology groups and the PCO rates were recorded accordingly to the ocular or nonocular pathologies.

\section{Statistical analysis}

Statistical analyses were computed with SPSS for Windows software (version 18.0, SPSS, Inc.) and Pearson Chi-Square test was applied when comparing rates for hydrophilic/ hydrophobic, spherical/ aspheric IOLs. Statistical significance was considered when $\mathrm{p}<0.05$.

\section{Results}

The current study comprised 4805 eyes from 3494 patients with a mean follow-up of 40 \pm 6.15 months (range from 27 to 54 months). There were 1810 (38\%) males and 2995 (62\%) females. The mean age at the last follow-up was $73 \pm 12$ years (range 21 to 98 years) with $80 \%$ of the patients between 60 to 90 years old. The patient age distribution is plotted in Fig. 1.

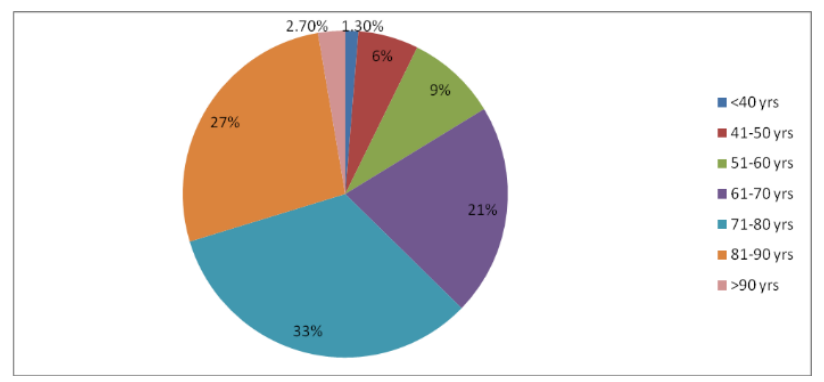

Fig. 1 Patient age distribution

All IOLs implanted during 2012 and 2013 at the Oculus Eye Clinic in Bucharest were included in the present study. Table 1 shows the IOLs evaluated and their pertinent characteristics. A total of 4805 IOLs were implanted, of which: 2937 (61\%) aspherical, 1868 (39\%) spherical, $2560 \quad(53.27 \%)$ hydrophilic and 2245 (45.73\%) hydrophobic.

Table 1. Type of lenses implanted and their characteristics

\begin{tabular}{|c|c|c|c|c|c|c|c|}
\hline LENS TYPE & $\%$ & $\begin{array}{l}\text { No of } \\
\text { cases }\end{array}$ & $\begin{array}{l}\text { Manufa } \\
\text { cturer }\end{array}$ & Material & Design & Haptic angulation & Optics \\
\hline $\begin{array}{l}\text { Acri.Tec } \\
\text { 47LC }\end{array}$ & $1 \%$ & 7 & $\begin{array}{l}\text { Acri. } \\
\text { Tec }\end{array}$ & $\begin{array}{l}\text { Hydrophilic } \\
\text { with cover }\end{array}$ & $\begin{array}{l}1 \text { piece with } \\
\text { loops }\end{array}$ & Plate haptics & Aspheric \\
\hline $\begin{array}{l}\text { Acri.Tec } \\
47 \mathrm{~S}\end{array}$ & $4 \%$ & 17 & $\begin{array}{l}\text { Acri. } \\
\text { Tec }\end{array}$ & $\begin{array}{l}\text { Hydrophilic } \\
\text { with cover }\end{array}$ & $\begin{array}{l}1 \text { piece with } \\
\text { loops }\end{array}$ & Plate haptics & Spherical \\
\hline Adapt-AO & $4 \%$ & 210 & B\&L & Hydrophilic & $\begin{array}{l}1 \text { piece } \\
\text { Square-edges }\end{array}$ & $\begin{array}{l}\text { One-piece } 4 \text { closed } \\
\text { loops } 0^{\circ} \text { angulation }\end{array}$ & $\begin{array}{l}\text { Aspheric } \\
\text { aberration - } \\
\text { free }\end{array}$ \\
\hline $\begin{array}{l}\text { Akreos- } \\
\text { Adapt }\end{array}$ & $1 \%$ & 6 & $B \& L$ & Hydrophilic & $\begin{array}{l}1 \text { piece } \\
\text { Square-edges }\end{array}$ & $\begin{array}{l}\text { One-piece } 4 \text { closed } \\
\text { loops } 0^{\circ} \text { angulation }\end{array}$ & Spherical \\
\hline $\begin{array}{l}\text { Aspheric } \\
\text { Ophtec }\end{array}$ & $02 \%$ & 1 & $\begin{array}{l}\text { Ophtec } \\
\text { BV }\end{array}$ & Hydrophobic & $\begin{array}{l}1 \text { piece with } \\
\text { loops }\end{array}$ & 2 closed loops $5^{\circ}$ & Aspheric \\
\hline $\begin{array}{l}\text { Bioline } \\
\text { Yellow }\end{array}$ & $6 \%$ & 273 & $\begin{array}{l}\text { iMedica } \\
\text { l }\end{array}$ & Hydrophilic & $\begin{array}{l}\text { 1-piece } \\
\text { square edges }\end{array}$ & C-loops $0^{\circ}$ & Spherical \\
\hline B-Lens & $2 \%$ & 108 & Hanita & Hydrophilic & $\begin{array}{l}\text { 1-piece } \\
\text { square edges }\end{array}$ & C -loops $5^{\circ}$ & Spherical \\
\hline CT 47LC & $2 \%$ & 96 & Zeiss & Hydrophilic & $\begin{array}{l}\text { 1-piece } \\
\text { square edges }\end{array}$ & C-loops $0^{\circ}$ & Aspheric \\
\hline CT 47S & $9 \%$ & 430 & Zeiss & Hydrophilic & $\begin{array}{l}\text { 1-piece } \\
\text { square edges }\end{array}$ & C-loops $0^{\circ}$ & Spherical \\
\hline $\begin{array}{l}\text { CT Xtreme } \\
\text { D }\end{array}$ & $04 \%$ & 2 & Zeiss & Hydrophilic & $\begin{array}{l}\text { 1-piece } \\
\text { square edges }\end{array}$ & C-loops $0^{\circ}$ & Spherical \\
\hline Dr Schmidt & $4 \%$ & 19 & $\begin{array}{l}\text { Human } \\
\text { Optics }\end{array}$ & Hydrophilic & $\begin{array}{l}\text { 1-piece } \\
\text { square edges }\end{array}$ & C Haptic $0^{\circ}$ & Spherical \\
\hline MA60AC & $4 \%$ & 17 & Alcon & Hydrophobic & $\begin{array}{l}\text { 3-pieces } \\
\text { sharp-edges }\end{array}$ & C-loops $10^{\circ}$ & Spherical \\
\hline
\end{tabular}




\begin{tabular}{|c|c|c|c|c|c|c|c|}
\hline MA60MA & $1 \%$ & 69 & Alcon & Hydrophobic & $\begin{array}{l}\text { 3-pieces } \\
\text { sharp-edges }\end{array}$ & C-loops $5^{\circ}$ & Spherical \\
\hline MC60T & $02 \%$ & 1 & & Hydrophobic & & & \\
\hline MI60 & $17 \%$ & 829 & B\&L & Hydrophilic & 1-piece & 4 haptics Slender $8^{\circ}$ & Aspheric \\
\hline MJ 14 & $4 \%$ & 21 & B\&L & Hydrophilic & $\begin{array}{l}\text { 1-piece sharp } \\
\text { edges }\end{array}$ & 4 haptics Slender $8^{\circ}$ & Aspheric \\
\hline MX60 & $3 \%$ & 124 & B\&L & Hydrophobic & $\begin{array}{l}\text { 1-piece post } \\
\text { square edges }\end{array}$ & Modified C & Aspheric \\
\hline MX60T & $1 \%$ & 54 & $B \& L$ & Hydrophobic & $\begin{array}{l}\text { 1-piece post } \\
\text { square edges }\end{array}$ & Modified C & Aspheric Toric \\
\hline $\begin{array}{l}\text { Ophtec } \\
\text { Monomax } \\
\text { PC550 }\end{array}$ & $6 \%$ & 299 & $\begin{array}{l}\text { Ophtec } \\
\text { BV }\end{array}$ & Hydrophilic & $\begin{array}{l}\text { 1-piece post } \\
\text { square edges }\end{array}$ & C-loop $5^{\circ}$ & Spherical \\
\hline $\begin{array}{l}\text { RAFI } \\
\text { FOLDABLE } \\
\text { S }\end{array}$ & $1 \%$ & 51 & $\begin{array}{l}\text { RAFI } \\
\text { Systems } \\
\text { Inc }\end{array}$ & Hydrophilic & $\begin{array}{l}\text { 1-piece } \\
\text { square edges }\end{array}$ & C-loop $0^{\circ}$ & Spherical \\
\hline SA60AT & $7 \%$ & 344 & Alcon & Hydrophobic & $\begin{array}{l}\text { 1-piece } \\
\text { square edges }\end{array}$ & C-loop $0^{\circ}$ & Spherical \\
\hline SeeLens & $4 \%$ & 191 & Hanita & Hydrophilic & $\begin{array}{l}\text { 1-piece } \\
\text { square edges }\end{array}$ & C-loop $5^{\circ}$ & Spherical \\
\hline SN60AT & $1 \%$ & 41 & Alcon & Hydrophobic & $\begin{array}{l}\text { 1-piece } \\
\text { square edges }\end{array}$ & C-loop $0^{\circ}$ & Spherical \\
\hline SN60WF & $22 \%$ & 1080 & Alcon & Hydrophobic & $\begin{array}{l}\text { 1-piece } \\
\text { square edges }\end{array}$ & C-loop $0^{\circ}$ & Aspheric \\
\hline SN6AD1 & $5 \%$ & 256 & Alcon & Hydrophobic & $\begin{array}{l}\text { 1-piece } \\
\text { square edges }\end{array}$ & C-loop $0^{\circ}$ & $\begin{array}{l}\text { Aspheric } \\
\text { multifocal }\end{array}$ \\
\hline SN6ATx & $5 \%$ & 252 & Alcon & Hydrophobic & $\begin{array}{l}\text { 1-piece } \\
\text { square edges }\end{array}$ & C-loop $0^{\circ}$ & Aspheric Toric \\
\hline SND1TX & $12 \%$ & 6 & Alcon & Hydrophobic & $\begin{array}{l}\text { 1-piece } \\
\text { square edges }\end{array}$ & C-loop $0^{\circ}$ & $\begin{array}{l}\text { Aspheric } \\
\text { multifocal } \\
\text { Toric }\end{array}$ \\
\hline $\begin{array}{l}\text { XLSTABI } \\
\text { SKI }\end{array}$ & $02 \%$ & 1 & Zeiss & Hydrophilic & $\begin{array}{l}\text { 1-piece } \\
\text { square edges }\end{array}$ & $10^{\circ}$ & Aspheric \\
\hline Total & $100 \%$ & 4805 & & & & & \\
\hline
\end{tabular}

The mean PCO and Nd-YAG rates for the hydrophilic group were $18 \%$ and $14 \%$, respectively and for the hydrophobic group, they were $4 \%$ and $2 \%$, respectively, finding a statistical significant difference between both groups $(\mathrm{p}<0.0001)$. We also found a statistical significant difference between the Nd-YAG rates of the spherical (3.8\%) and aspheric lenses $(10 \%)(\mathrm{p}=0.000)$, but these spherical/ aspheric lenses groups showed large differences in the distribution of the lens types. We further divided these two large groups in sub-groups following material and lens optic/ haptic design.

The distribution of lenses in these subgroups with their PCO and Nd-YAG Rates are shown in Table 2 . No statistically significant differences were found between hydrophobic aspheric (C-Loop) and hydrophobic spherical IOLs (C-Loop) for PCO ( $>0.05)$ and Nd:YAG rates ( $>0.05$ ). Regarding the hydrophilic IOL group, there were statistical significant differences between aspheric and spherical IOLs for PCO $(p<0.0001)$ and $\mathrm{Nd}$ :YAG rates $(\mathrm{p}<0.0001)$. However, in the sub-group of hydrophilic aspheric IOLs, $89 \%$ of the lenses had a broad optic/ haptic junction and only $11 \%$ a C-Loop design in contrast to the C-loop haptic configuration found in all hydrophilic spherical lenses. 
Table 2. The subgroup of lenses with their Posterior Capsule Opacification (PCO) and Nd-YAG rates

\begin{tabular}{|c|c|c|c|c|c|c|c|c|}
\hline $\begin{array}{l}\text { TYPE OF } \\
\text { LENSES }\end{array}$ & $\begin{array}{l}\text { No (\% of } \\
\text { total) }\end{array}$ & SUBTYPE & $\begin{array}{l}\text { No (\% of } \\
\text { total) }\end{array}$ & $\begin{array}{l}\text { PCO } \\
\text { Rate }\end{array}$ & $\begin{array}{l}\text { Nd- } \\
\text { YAG } \\
\text { Rate }\end{array}$ & $\begin{array}{c}\text { Haptic } \\
\text { Configurati } \\
\text { on }\end{array}$ & $\begin{array}{l}\text { PCO } \\
\text { Rate }\end{array}$ & $\begin{array}{l}\text { Nd- } \\
\text { Yag } \\
\text { Rate }\end{array}$ \\
\hline & 2937 (61\%) & $\begin{array}{l}\text { HYDROPHIL } \\
\text { IC }\end{array}$ & $\begin{array}{c}1164 \\
(39.6 \%)\end{array}$ & $\begin{array}{c}27.68 \\
\%\end{array}$ & $22.3 \%$ & $\begin{array}{c}\text { Broad } \\
\text { optic/ } \\
\text { haptic } \\
\text { junction } \\
(89 \%)\end{array}$ & $\begin{array}{c}29.75 \\
\%\end{array}$ & $\begin{array}{c}24.73 \\
\%\end{array}$ \\
\hline & & & & & & $\begin{array}{l}\text { C-Loop } \\
(11 \%)\end{array}$ & $\begin{array}{c}12.6 \\
\%\end{array}$ & $3.3 \%$ \\
\hline & & $\begin{array}{c}\text { HYDROPHO } \\
\text { BIC }\end{array}$ & $\begin{array}{c}1773 \\
(60.4 \%)\end{array}$ & $4.02 \%$ & $2 \%$ & $\begin{array}{l}\text { C-Loop } \\
(100 \%)\end{array}$ & $\begin{array}{c}4.02 \\
\%\end{array}$ & $2 \%$ \\
\hline \multirow[t]{2}{*}{$\begin{array}{l}\text { SPHERICAL } \\
\text { LENSES }\end{array}$} & $1868(39 \%)$ & $\begin{array}{l}\text { HYDROPHIL } \\
\text { IC }\end{array}$ & $\begin{array}{c}1396 \\
(74.73 \%)\end{array}$ & $7.64 \%$ & $5.1 \%$ & $\begin{array}{l}\text { C-Loop } \\
(100 \%)\end{array}$ & $\begin{array}{c}7.64 \\
\%\end{array}$ & $5.1 \%$ \\
\hline & & $\begin{array}{c}\text { HYDROPHO } \\
\text { BIC }\end{array}$ & $\begin{array}{c}472 \\
(25.27 \%)\end{array}$ & $5.29 \%$ & $1.9 \%$ & $\begin{array}{l}\text { C-Loop } \\
(100 \%)\end{array}$ & $\begin{array}{c}5.29 \\
\%\end{array}$ & $1.9 \%$ \\
\hline
\end{tabular}

Analyzing the PCO and Nd:YAG rates for the sub-group of hydrophilic aspheric IOLs with different haptics configuration, we found statistically significant differences $(p<0.001)$ for the PCO and Nd:YAG rates between the group of IOLs with broad optic/ haptic junction $(29.75 \%$ and $24.73 \%$ rates, respectively) and C-Loop haptics $(12.6 \%$ and $3.3 \%$, respectively). In contrast, comparing the PCO and Nd:YAG rates of the hydrophilic aspheric sub-group with C-loop configuration $(12.6 \%$ and $3.3 \%$, respectively) versus the hydrophilic spherical sub-group with the same haptics configuration $(7.64 \%$ and $5.1 \%$ rates, respectively), no statistically significant differences were found ( $p>0.05$ ).

The study also followed concurrent ocular and general pathology and their influence on PCO and Nd-YAG rates. Table 3 shows the distribution of patients for each pathology group.

Table 3. Distribution of patients for each pathology group

OCULAR PATHOLOGY

GENERAL PATHOLOGY

Age Related Macular Degeneration

$21 \%(n=992)$

Glaucoma 14\% (n=656)

Type II Diabetes $15 \%$

$(n=734)$

Pseudoexfoliative Syndrome 8\%

$(\mathrm{n}=370)$

Intravitreal Injections 1\% $(\mathrm{n}=40)$

GENAL PATHOLOGY

Table 4 shows the PCO rates for each pathology group with the additional information of the percentage of hydrophilic lenses per group. There were no statistically significant correlations between the ocular associated pathologies and PCO rates $(\mathrm{p}>0.05)$.

\begin{tabular}{|ll} 
& No Diabetic Retinopathy \\
Oral medication & $80 \%$ \\
$69 \%$ & Background Diabetic \\
& Retinopathy \\
& $16 \%$ \\
Insulin & Proliferative Diabetic \\
$17 \%$ & Retinopathy \\
Diet & $3 \%$ \\
$14 \%$ & Diabetic Maculopathy \\
ment $\sim$ 1\% (n=59) & $1 \%$ \\
\end{tabular}

Table 4. PCO rate for each pathology group

\begin{tabular}{|c|c|}
\hline PATHOLOGY & Rate of PCO \\
\hline $\begin{array}{l}\text { Diabetes } \\
(\mathrm{n}=734)\end{array}$ & $\begin{array}{l}\mathbf{6 \%}(\mathrm{n}=46)-47 \% \\
\text { hydrophilic lenses }\end{array}$ \\
\hline $\begin{array}{l}\text { Age Related Macular } \\
\text { Degeneration } \\
(\mathrm{n}=992)\end{array}$ & $\begin{array}{l}\mathbf{1 2 \%}(\mathrm{n}=123)-62 \% \\
\text { hydrophilic lenses }\end{array}$ \\
\hline
\end{tabular}


Glaucoma

$(\mathrm{n}=656)$

Pseudoexfoliation

Syndrome

$(\mathrm{n}=370)$

General Cortisone treatment

$(n=59)$

\section{Conclusions}

In the current study, a total of 4805 implanted IOLs were evaluated. The incidence of the PCO and Nd:YAG rates were assessed after a mean of $40 \pm 6.15$ months of follow up (from 27 to 54 months). The analysis showed that PCO and Nd:YAG rates were statistically significantly higher in those eyes implanted with hydrophilic IOLs than with hydrophobic IOLs. Therefore, IOL material seems to be a determinant factor for PCO occurrence and need of Nd-YAG laser treatment after uneventful cataract surgery. Our results were in accordance with several studies that have shown a correlation between PCO rates and optic material $[\mathbf{1 3 , 1 4}]$. Hydrophilic IOLs have been associated with higher rates of PCO than hydrophobic IOLs $[\mathbf{1 6}, \mathbf{1 7}]$.

Regarding the IOL characteristics/ material, many studies comparing square-edged hydrophobic and hydrophilic acrylic IOLs [1720] have shown that hydrophilic IOLs perform less favorably than hydrophobic IOLs in terms of PCO prevention.

Regarding the IOL asphericity, we did not find any significant correlation for PCO and Nd:YAG occurrence. Besides, that hydrophilic aspheric IOLs sub-group showed statistically significant higher PCO and Nd:YAG rates than hydrophilic spherical IOLs, these results being mainly attributed to the fact that in the subgroup of hydrophilic aspheric IOLs, $89 \%$ of the lenses had a broad optic/ haptic junction with high PCO and Nd-YAG rates and only 11\% showed a C-Loop design in contrast to the C-loop haptic configuration found in all hydrophilic spherical lenses. Our statistical analysis confirmed that, for the hydrophilic lenses, we found significantly higher PCO and Nd:YAG rates for the IOLs with the broad optic-haptic junction than for those with the C-loop configuration without any correlation to the asphericity. In contrast, when we compared the PCO and Nd:YAG rates of the hydrophilic aspheric subgroup with C-loop configuration $(12.6 \%$ and $3.3 \%$, respectively) versus the hydrophilic spherical sub-group with the same haptics configuration $\quad(7.64 \%$ and $5.1 \%$ rates, respectively), no statistically significant differences were found $(p>0.05)$.

The broad gap in the squared-edged barrier at the broad optic-haptic junction of an IOL has been described as the Achilles heel in PCO prevention as it provides a point of migration for LECs from the equatorial region of the capsule onto the central posterior capsule [21].

We noticed a lot of variability in PCO and Nd:YAG rates among the different hydrophilic IOL models evaluated. These differences might be due to the differences in the haptics and edges design. In contrast, regarding to the hydrophobic IOLs group, all the lenses showed very similar PCO and Nd:YAG rates, with very similar IOL design characteristics.

Concerning the different pathology groups, our study found no statistically significant correlations between the ocular associated pathologies and PCO rates ( $p>0.05)$.

Being a retrospective analysis conducted on a large number of eyes, this study had some limitations. One limitation was that the groups of IOLs formed by model were not equal in size and the distribution of IOLs among different pathology groups was not the same. Another limitation was the use of the CTR or Femtolaser in some particular cases or some intravitreal injections done at the end of the surgeries.

Despite the minimal limitations, our study had many strong points. We managed to include a large sample of eyes with a high diversity of IOLs implanted and we followed these eyes for a long period of time. Being also able to perform Nd-YAG laser treatment on site, all our patients who developed PCO and needed to be treated, could come to the clinic and receive proper care.

Our study also showed that not only the material of the IOL was a determinant factor for PCO formation, but also the design of the optic/ haptic. The C-Loop design performed statistically better in terms of PCO prevention compared to the broad optic/ haptic junction configuration despite same hydrophilic material and similar edges configuration. Our analysis led to the 
additional conclusion that asphericity or coexisting ocular or non-ocular pathology did not influence the PCO occurrence.

\section{Acknowledgments:}

Dr. Iliescu, Constantin and Cozma were supported by a research Grant from Alcon Laboratories, Inc. (Alcon Romania S.R.L., located at 301-311 Barbu Văcărescu Blvd., Lake View Building, 5th floor, district 2, Bucharest, Romania, IIT Grant No. 20949341).

No authors have any financial interest in a product, method, or material presented in the article.

The article was presented in the following meetings:

IIIrd Congress of the Romanian Society of Cataract and Refractive Surgery - Eforie Nord, Romania, 23-26 June 2016;

The XXXIV Congress of the European Society of Cataract and Refractive SurgeonsCopenhagen, Denmark, 10-14 Sept 2016;

$X V^{\text {th }}$ National Congress of the Romanian Society of Ophthalmology - Sinaia, Romania, 5-8 October 2016.

\section{References}

1. Colin J, El Kebir S, Eydoux E, Hoang-Xuan T, Rozot P, Weiser M. Assessment of patient satisfaction with outcomes of and ophthalmic care for cataract surgery. J Cataract Reract. Surg. 2010; 36:1373-1379.

2. Buehl W, Sacu S, Findl O. Association between intensity of posterior capsule opacification and contrast sensitivity. Am J Ophthalmol. 2005; 140:927-930.

3. Schriefl S, Menapace R, Stifter E, Zaruba D, Leydolt C. Posterior capsule opacification and neodymium:YAG laser capsulotomy rates with 2 microincision intraocular lenses: Four-year results. J Cataract Reract. Surg. 2015; 41:956-963.

4. Magno BV, Datiles MB, Lasa MSM, Fajardo MR, Caruso RC, Kaiser-Kupfer MI. Evaluation of visual function following neodymium:YAG laser posterior capsulotomy. Ophthalmology. 1997; 104:1287-1293.

5. Claesson M, Klarén L, Beckman C, Sjöstrand J. Glare and contrast sensitivity before and after Nd:YAG capsulotomy. Acta Ophthalmol. 1994; 72:27-32.

6. Hayashi K, Hayashi H, Nakao F, Hayashi F. Correlation between posterior capsule opacification and visual function before and after neodymium:YAG laser posterior capsulotomy. Am J Ophthalmol. 2003; 136:720-726.

7. Wakamatsu TH, Yamaguchi T, Negishi K, Kaido M, Matsumoto Y, Ishida R, Kojima T, Ibrahim OMA, Saiki M, Dogru M, Tsubota K. Functional visual acuity after
neodymium:YAG laser capsulotomy in patients with posterior capsule opacification and good visual acuity preoperatively. J Cataract Refract Surg. 2011; 37:258264.

8. Knighton RW, Slomovic AR, Parrish RK II. Glare measurements before and after neodymium-YAG laser posterior capsulotomy. Am J Ophthalmol. 1985; 100:708-713.

9. Sunderraj P, Villada JR, Joyce PW, Watson A. Glare testing in pseudophakes with posterior capsule opacification. Eye. 1992; 6:411-413. http://www.nature.com/eye/journal/v6/n4/pdf/eye1 99285a.pdf.

10. Menon GJ, Wong KK, Bundhun T, Ewings P, Twomey JM. The effect of $\mathrm{Nd}$ :YAG laser posterior capsulotomy on stereoacuity. Eye. 2009; 23:186-189. http://www.nature.com/eye/journal/v23/n1/pdf/67 02932a.pdf.

11. Billotte C, Berdeaux G. Adverse clinical consequences of neodymium:YAG laser treatment of posterior capsule opacification. J Cataract Refract Surg. 2004; 30(10):2064-2071.

12. Buehl W, Findl O. Effect of intraocular lens design on posterior capsule opacification. J Cataract Refract Surg. 2008; 34:1976-1985.

13. Meacock WR, Spalton DJ, Hollick EJ, Barman S, Boyce JF. The effect of polymethylmethacrylate and AcrySof intraocular lenses on the posterior capsule in patients with a large capsulorrhexis. Jpn J Ophthalmol. 2001; 45:348-354.

14. Versura P, Torreggiani A, Cellini M, Caramazza R. Adhesion mechanisms of human lens epithelial cells on 4 intraocular lens materials. J Cataract Refract Surg. 1999; 25:527-533.

15. Wejde G, Kugelberg M, Zetterström C. Position of anterior capsulorhexis and posterior capsule opacification. Acta Ophthalmol Scand. 2004; 82:531534.

http://onlinelibrary.wiley.com/doi/10.1111/j.16000420.2004.00322.x/pdf.

16. Heatley CJ, Spalton DJ, Kumar A, Jose R, Boyce J, Bender LE. Comparison of posterior capsule opacification rates between hydrophilic and hydrophobic single-piece acrylic intraocular lenses. J Cataract Refract Surg. 2005; 31:718-724.

17. Kugelberg M, Wejde G, Jayaram H, Zetterström C. Twoyear follow-up of posterior capsule opacification after implantation of a hydrophilic or hydrophobic acrylic intraocular lens. Acta Ophthalmol. 2008; 86:533-536. http://onlinelibrary.wiley.com/doi/10.1111/j.16000420.2007.01094.x/pdf.

18. Gangwani V, Hirnschall N, Koshy J, Crnej A, Nishi Y, Maurino V, Findl O. Posterior capsule opacification and capsular bag performance of a microincision intraocular lens. J Cataract Refract Surg. 2011; 37:1988-1992.

19. Žemaitienė $R$, Špečkauskas $M$, Glebauskienė $B$, Jašinskas V. Comparison of postoperative results after implantation of hydrophilic acrylic or hydrophobic acrylic intraocular lens: data of one-year prospective clinical study. Medicina. 2008; 44:936-943. http://medicina.lsmuni.lt/med/0812/0812-04l.pdf. 
20. Vasavada AR, Raj SM, Shah A, Shah G, Vasavada V, Vasavada V.Comparison of posterior capsule opacification with hydrophobic acrylic and hydrophilic acrylic intraocular lenses. J Cataract Refract Surg. 2011; 37:1050-1059.

21. Sugita M, Kato S, Sugita G, Oshika T. Migration of lens epithelial cells through haptic root of single-piece acrylic-foldable intraocular lens. Am Ophthalmol. 2004; 137:377-379. 